\title{
長崎県壱岐島における隠居慣行の様相 \\ 隠居慣行の継承と変容に関する研究その 2 \\ THE ASPECT OF THE CUSTOM OF RETIREMENT FROM THE HEADSHIP OF FAMILY IN IKI ISLAND
}

Study on the succession and the transfiguration in the custom of retirement from the headship of family Part 2

\section{上和田 茂*, 船 越 正 啓** \\ Shigeru KAMIWADA and Masahiro FUNAKOSHI}

\begin{abstract}
The aim of this research is to make it clear how the custom of retirement from the headship of family has been succeeded and changed in Iki island. The summary of this research is as follows;

It is thought that the custom of retirement from the headship of family in Iki island has been succeeded, from the separate living type has been shown in over 60 percent of the examined two-generation families. However this custom has shown the aspect of the diversification, because the custom of economic independence and separated eating style has been collapsing in some districts. According these changing, the aspect of the act area in the residential site also has been diversified and can be classified into three groups, the type of mutual independence, the type of mutual help and the type of communal life.
\end{abstract}

Keywords: custom of retirement from the headship of family, living next door, house for two-generation family, residential relationship between parents and heir family, the aged society, Iki island 隠居慣行，隣居，二世帯住宅，親子の居住関係，高齢社会，壱岐島

\section{1. 研究の目的と方法}

西南日本に特有の通世代居住形態とみなされていた父子二世代不 同居を原則とする隠居慣行は、近年の社会的・経済的条件の変化、 生産および生活構造の合理化や近代化の進行に伴い、次第に消滅し つつある。しかし、このような状況にあっても、今なお隠居慣行が 明確に存続する地域が近畿地方以西の各地に点在している。本研究 の対象である長崎県壱岐島もその一つである。

かつてわが国において大勢を占めていた三世代同居は近年減少の 一途にある。これに代わって、隣居、近居、準近居注 1 といった、親 子両世帯が適度な距離を保って相互独立の生活を保持しつつも、同 時に両世帯間の相互支援を可能と寸る様々な居住形態が増加の傾向 にあり、親子の居住関係はまさに多様化の様相を呈している。

一方、隠居慣行が継承されている地域にあっても、隠居慣行にお ける基本的な親子居住関係である隣居形態の慣習が薄れ、部分的に 同居形態へと変化しつつある実態もみられ、前述の同居から他の親 子居住関係への変化とは逆行寸るかたちでの多様化が進行している。 このようなことから、隠居慣行の継承と変容の様相を明らかにす ることは、親子の居住関係における多様化の全体像を解明すること に寄与すると共に、今後の動向を展望するうえで貴重な示唆を与え
るものと考えられる。

同時に、隠居慣行における伝統的な隣居の变質の状況およびその 要因を明らかにすることは、現代における隣居の有効性と可能性お よび問題点を論じる上での有益な情報を提供することになろう。

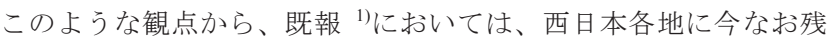
る隠居慣行を対象に、その継承と変容の過程の概要を明らかにした。 本報は、その続報として、長崎県壱岐島の 3 地区を取り上げ、 3 地 区間及び壱岐島以外との比較を交えて、隠居慣行の詳細な実態を明 らかにすることを目的とする。壱岐島における隠居慣行は同じ島に ありながら地区毎にそれぞれの特質を異にしており、多様化の様相 を論じる上で格好の対象といえる。

\section{2. 隠居慣行の概説および既往研究}

一般に隠居とは、老後、家長の地位・権限を次代に譲り、退隠の 境遇に入ることを言い、「同居隠居」「別居隠居（単独別居、家族別 居、隠居分家)」「分住隠居」に大別される。同居と別居は隠居者が 相続人と同じ屋根の下に住むか否かにより区分される。最も多いの は別居隠居であるが、単独別居は親夫婦だけが隠居に移り、家族別 居は次男以下を連れて出る。隠居分家は、連れて出た次男以下に隠

\footnotetext{
本研究は, 住宅系研究報告会論文集 1 に発表した内容 ${ }^{2}$ を修正・加筆したものである。

*九州産業大学工学部住居インテリア設計学科教授·工博Ｐrof., Dept. of Housing \& Interior Design, Faculty of Engineering, Kyushu Sangyo Univ.,

** 九州産業大学工学部建築学科 講師 ·博士 (工学) Dr. Eng. Lecturer, Dept. of Architecture, Faculty of Engineering, Kyushu Sangyo Univ., Dr. Eng.
} 
居屋を譲って分家を創設させ、自身は再度隠居を行う。分住隠居は、 父親は本家に、母親は分家に分かれて隠居するものを指す。なお、 今日の主流はいずれの地においても単独別居隠居である。 ${ }^{4) 5}$

既往研究としては、民俗学において、伝統的な家制度および家族 形態の考察を目的として系統的に研究が進められてきているが、居

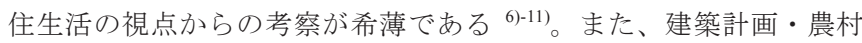
計画の領域においても事例的研究が行われており、本研究を展開す る上で多くの示唆を得た ${ }^{12-18)}$

本研究は、西日本各地の隠居慣行との比較を交えて壱岐島におけ る隠居慣行の特質を明らかにするものであるが、同時に、隠居慣行 および慣行の要諦である親子両世帯の隣居形態の変容過程に注目し て考察することを通して、現代における隣居の有効性と問題点を論 じる上での示唆を得ることを目的としている。特に、既報では基本 的な側面にしか触れ得なかった親子両世帯間の生活関係について、 居住領域構成の視点から詳細に考察する。

\section{3. 調査概要}

壱岐島における調查対象地区は、親子二世帯居住の比率の高さお よび居住形態の差異を考慮して、壱岐市勝本町片山地区、芦辺町諸 吉地区、郷ノ浦町渡良西地区の 3 地区を選定した。各地区ともに予 備調查から親子二世帯居住であることが判明済みの住戸を対象とし て、調査拒否および不在の場合を除く全戸において訪問調查を行っ た。調査内容は、家屋配置および各家屋の平面採取を行うとともに、 家屋の建設歴、家族構成、居住形態の経年変化、現在の住まい方、 将来への居住志向等について居住者から聴取した。なお、西日本各 地の隠居慣行との比較を行うため、壱岐島以外の 7 地区において同 様の調查を行っている。調查対象地区の位置を図 1 、図 2 に示寸。

\section{4. 調査対象地区の概要}

壱岐島は、全土の 8 割が標高 $100 \mathrm{~m}$ 以下のなだらかな丘陵を成し、 図 3 に示すように、農村集落において各屋敷が北側の防風林を背に
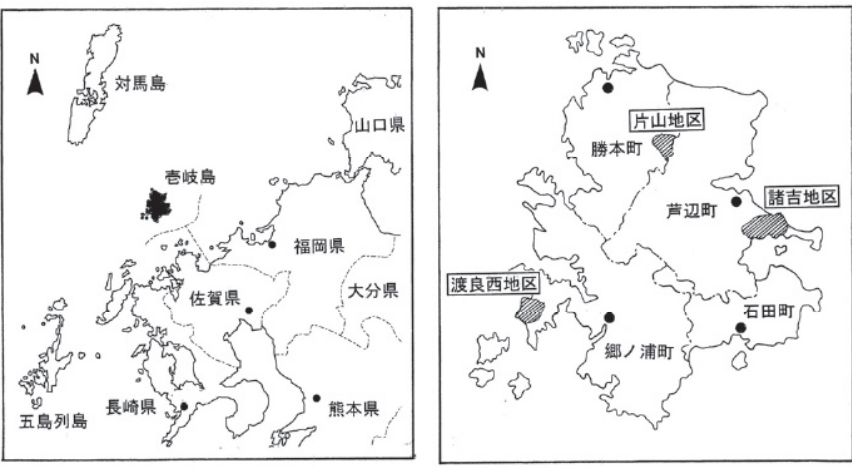

図 1 壱岐島および調査対象地区の位置

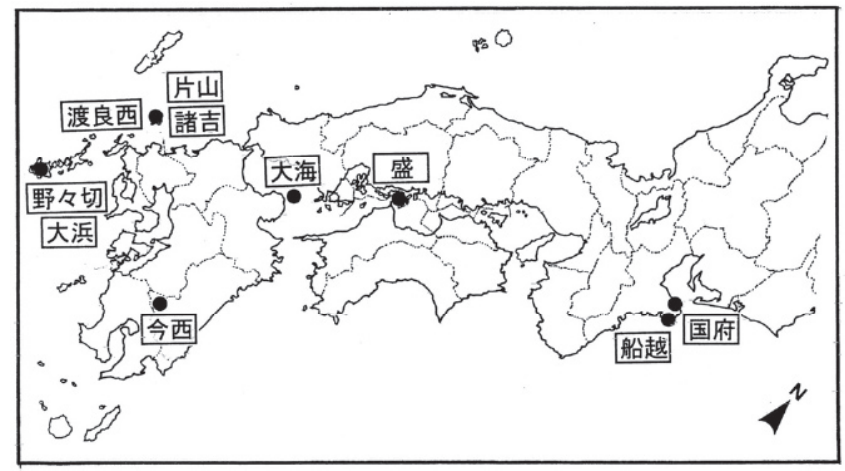

図 2 西日本地域における調査対象地の位置

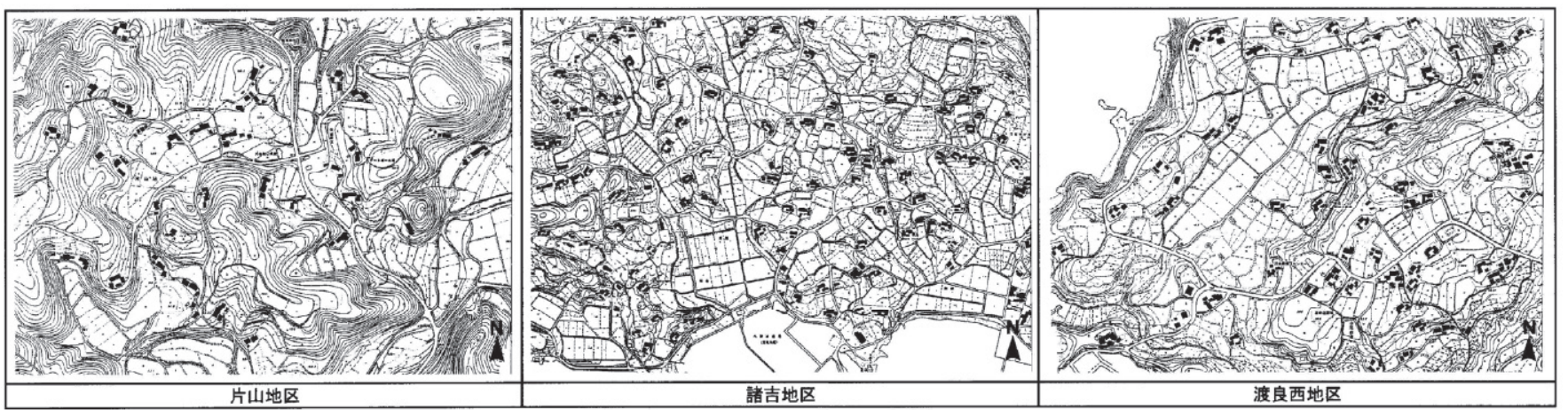

図 3 調査対象地区の地形および家屋分布

表 1 調查概要および調査対象地区の概要

\begin{tabular}{|c|c|c|c|c|c|c|c|c|c|c|c|c|}
\hline \multirow{2}{*}{\multicolumn{2}{|c|}{ 地区名 }} & \multirow{2}{*}{ 所在地 } & \multirow{2}{*}{ 主要産業 } & \multirow{2}{*}{ 集落形態 } & \multirow{2}{*}{ 世带数 } & \multirow{2}{*}{$\begin{array}{l}\text { 親子 } \\
\text { =世世结居 } \\
\text { 住事例数 }\end{array}$} & \multicolumn{2}{|c|}{ 平均年粗 } & \multirow{2}{*}{ 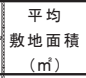 } & \multicolumn{2}{|c|}{ 調査時期 } & \multirow{2}{*}{$\begin{array}{c}\text { 調查 } \\
\text { 刘象 } \\
\text { 事例数数 }\end{array}$} \\
\hline & & & & & & & 親 (夫) & 子(夫) & & 第1回調查 & 第2回調查 & \\
\hline \multirow{3}{*}{ 壱岐島 } & 片山 & 長崎県壱岐市勝本町 & 農業(米作) & 散居集落 & 37 & 17 & 68.7 & 42.7 & 959 & 1993年 8月 2日〜 3日 & 2001年11月 3日〜 4日 & 15 \\
\hline & 諸吉 & 長崎県壱岐市芦辺町 & 農業(米作、葉タバコ)、漁業(採取的漁獑) & 散居集落 & 177 & 43 & 68.6 & 41.5 & 954 & 1993年 8月 3日 4日 & 2001年11月 3日 4日 & 28 \\
\hline & 渡良西 & 長崎県壱岐市鄉ノ浦町 & 農業 (米作)、漁業 (採取的漁猟) & 散居集落 & 59 & 40 & 70.7 & 43.4 & 740 & 1992年 7月13日 15日 & 2001年11月 3日～4日 & 19 \\
\hline \multirow{7}{*}{$\begin{array}{l}\text { 壱岐島 } \\
\text { 以外 }\end{array}$} & 国府 & 三重県志摩市阿児町 & 農業(米作)、漁業 (採取的漁猙：海藻類) & 集居集落 & 404 & 47 & 68.3 & 46.0 & 841 & 1994年11月22日 26日 & 2002年 8月24日 25日 & 18 \\
\hline & 船越 & 三重県志摩市大王町 & 真珠養殖、漁業 (採取的漁诵：貝類) & 塊村 & 753 & 141 & 71.3 & 43.9 & 258 & 1994年11月22日 26日 & 2002年 8月24日 25日 & 18 \\
\hline & 盛 & 愛媛県今治市上浦町 & 農業 (米作、果樹) & 塊村 & 333 & 47 & 71.9 & 44. 9 & 538 & 1994年 8月 1日 3日 & 2002年 3月12日 13日 & 34 \\
\hline & 大海 & 大分県東国東郡姫島村 & 漁業 & 塊村 & 66 & 32 & 69.5 & 39.8 & 420 & 1996年10月28日 31日 & 2002年 2月10日 11日 & 30 \\
\hline & 今西 & 宮崎県えびの市 & 農業 (米作) & 集居集落 & 83 & 29 & 69.1 & 41.4 & 1,018 & 1994年10月31日 11月1日 & 2002年 3月 9日 10日 & 8 \\
\hline & 野々切 & 長崎県五島市 & 農業(㚼作：麦、甘茥。葉タバコ) & 集居集落 & 212 & 34 & 75.2 & 46.7 & 913 & 1995年 9月30日 10月3日 & 2002年 2月23日 24日 & 19 \\
\hline & 大浜 & 長崎県五島市 & $\begin{array}{l}\text { 農業(畑作：葉タバコ)、漁業 } \\
\end{array}$ & 集居集落 & 246 & 58 & 74.8 & 49.4 & 683 & 1995年 9月30日 10月3日 & 2002年 2月23日 24日 & 23 \\
\hline
\end{tabular}

注)世帯数は非農家と転入者を含む第1回調査時の世帯数で、宅地が異なる近居の場合は親世帯と子世帯が別々にカウントされている。

親子二世帯居住事例数は自治会長·公民館長他からの聞き取りによる。平均年齢は調査対象の第 1 回調査時の平均年齢。平均敷地面積は調查対象の実測平均敷地面積 (近居は本家の実測面積)。 
して散居を形成しているのが特徵的である。

表 1 に示すように、片山地区は、内陸部の山間部に位置し、37世 帯の小集落を構成寸る。谷間ながら水田耕作が盛んで、農業収入も 比較的多いが、近年は専業農家が減少気味である。

諸吉地区は、島東部の半島に位置し、調査対象とした本村触（壱 岐では集落を触という) で 70 世帯、南触で 107 世帯が分布する。主 要産業は農業であるが、漁港や磯に近いため漁業も盛んである。

渡良西地区は、島南西部の半島に位置し、59 世帯を構成する。中 央部の低地に馬蹄形状に水田が広がり、それを取り巻く丘陵部に各 屋敷が点在する。農業主体ではあるが、採取的漁業もみられる。

\section{5. 壱岐島における隠居慣行の様相}

\section{1 隠居屋の建設状況の推移}

表 2 に示すように、3 地区ともに、隠居屋は戦後においても着実 に建設され、更新されてきている。近年においても、子供が結婚し、 世帯分離が必要な時期が訪れると、老朽化して住みづらくなった隠 居屋を建て替える事例が多くみられる。1980 年代以降でみても、片 山地区で 7 件、諸吉地区で 9 件、渡良西地区で 4 件が更新されてい る。このような隠居屋の建設状況からみても、壱岐島では、今なお 隠居慣行が継承されていることが認められる。

一方、表 3 に示寸ように、本家（母屋のこと。以下、本家という） の建て替えの際に、老朽化した隠居屋を同時に撤去し、本家で親子 両世帯が同居するように移行した事例が、1950 年代以降、片山地区 で 2 件、諸吉地区で 3 件、渡良西地区で 7 件みられ、隠居慣行から の離脱の一面もうかがえる。ただし、子供が結婚適齢期に達してい なかったため老朽化した隠居屋を撤去した事例において、将来、隠 居屋を復活させたいとの意向を持つ居住者も少なくはなく、今後の 動向についての単純な解勫は避けなければならない。

表 2 隠居屋の建設時期

\begin{tabular}{|c|c|c|c|c|c|c|c|c|}
\hline 地区名 年代 & $\begin{array}{l}1939 \\
\text { 以前 }\end{array}$ & $\begin{array}{l}1940 \\
\text { 年代 }\end{array}$ & $\begin{array}{l}1950 \\
\text { 年代 }\end{array}$ & $\begin{array}{l}1960 \\
\text { 年代 }\end{array}$ & $\begin{array}{l}1970 \\
\text { 年代 }\end{array}$ & $\begin{array}{l}1980 \\
\text { 年代 }\end{array}$ & $\begin{array}{l}1990 \\
\text { 年代 }\end{array}$ & 合計 \\
\hline 片 山 地区 & 1 & 0 & 11) & 0 & 4 & 5 & 2 & 13 \\
\hline 諸 吉 地区 & 52) & 23) & 4 & 2 & 43) & 83) & 1 & 26 \\
\hline 渡良西地区 & 1 & 2 & 0 & 5 & 1 & 3 & 14) & 13 \\
\hline 合 計 & 7 & 4 & 5 & 7 & 9 & 16 & 4 & 52 \\
\hline
\end{tabular}

注1）1）現在非使用、2) 2 件が現在非使用、3) 1 件が現在非使用、4) 調査時建設中 注2）諸吉地区および渡良西地区では、各1例ずつ複数回(2回)の建設事例が含まれている。 注3）建設年代の特定は、調査対象世帯へのヒアリングによる。

表 3 隠居屋の撤去時期

\begin{tabular}{|c|c|c|c|c|c|c|c|c|}
\hline 地区名 年代 & $\begin{array}{c}1939 \\
\text { 以前 }\end{array}$ & $\begin{array}{c}1940 \\
\text { 年代 }\end{array}$ & $\begin{array}{c}1950 \\
\text { 年代 }\end{array}$ & $\begin{array}{c}1960 \\
\text { 年代 }\end{array}$ & $\begin{array}{c}1970 \\
\text { 年代 }\end{array}$ & $\begin{array}{c}1980 \\
\text { 年代 }\end{array}$ & $\begin{array}{c}1990 \\
\text { 年代 }\end{array}$ & 合計 \\
\hline 片山地区 & 0 & 0 & 0 & 0 & 1 & 1 & 0 & 2 \\
\hline 諸 吉 地区 & 0 & 0 & 0 & 0 & 1 & 2 & 0 & 3 \\
\hline 渡良西地区 & 0 & 0 & 1 & 0 & 5 & 1 & 0 & 7 \\
\hline 合 計 & 0 & 0 & 1 & 0 & 7 & 4 & 0 & 12 \\
\hline
\end{tabular}

\section{2 居住形態の様相}

別居隠居は、言うまでもなく親子両世帯が本家と隠居屋に分かれ て居住することを原則とする。両者の居住内容の分離度は日常生活 全般を含めて判断する必要があるが、ここでは既往研究にならい、 まず親子両世帯の「寝室」の分離度により居住形態を分類する。す なわち、両者の寝室が本家と隠居屋に分かれているものを「分棟居 住（以下、分棟という）」、本家内に併存するものを「同棟居住（以 下、同棟という)」とする。また、分棟ではあるが、廊下等により連 結されているものを「続棟居住（以下、続棟という）」とする。注2)

図 4 に示寸ように、片山地区では、分棟が $60 \%$ 、続棟が $20 \%$ 、同 棟が $20 \%$ 、諸吉地区では、分棟が $71 \%$ 、続棟が $4 \%$ 、同棟が $25 \%$ 、 渡良西地区では、分棟が $63 \%$ 、同棟が $37 \%$ といった分布となってい る。渡良西地区において同棟がやや多く、分離度が低い傾向がみら れるものの、いずれの地区においても分棟は 60〜 70\%台に分布して おり、地区間での大きな差異は認められない。すなわち、寝室の分 離度においては、いずれの地区も比較的高い数值を維持しており、 別居隠居の風習はかなりの程度継承されているとみることができる。

\section{3 居住形態・食事形態・家計からみた様相}

上記の「居住形態」に「食事形態」および「家計」を加え、より 詳しく居住状況をみる。「食事形態」は食事注 3)を親子両世帯で共に するものを「共食」、別々にとるものを「別食」に区分し、「家計」 は基本的支出注4)を親子両世帯で一元化しているものを「同計」、別々 にしているものを「別計」に区分し、それぞれの比率を算出した。

図 5 に示すように、片山地区では、別食率が $80 \%$ 、別計率が $67 \%$ と、寝室の分離度が高いことにとどまらず、食事形態および家計の 面でも分離度が高く、生活全般において親子両世帯の相互独立性が 高いことが認められる。これに比較すると、諸吉地区では、別食率、 別計率共に $14 \%$ 、渡良西地区でも、別食率が $21 \%$ 、別計率が $16 \%$ に過ぎず、生活の内実が同居に近いものであることが推察される。

\section{4 西日本各地の隠居慣行との比較}

このように、地区間により生活の分離度に差異があり、隠居慣行 の継承度に摇らぎがみられることが判明した。そこで、この摇らぎ の持つ意味を確認するため、西日本各地の隠居慣行との比較を試み る。なお、壱岐を含む全地区において、別食率と別計率は概初同様 の数值を示していることから「別食率」に代表させ、「分棟率」と「別 食率」の 2 軸により各地区の特質を表すことにする。この 2 軸によ る座標に全 10 地区をプロットしたものが図 6 である。なお、各地区 の位置および概要等については前出の図 2 および表 1 に示した。

図 6 によると、10 地区は大きく 3 つのグループに類型化すること ができる。すなわち、分棟率 $80 \%$ 以上、別食率 $50 \%$ 以上で、両者が 共に高い数值を示寸第 1 グループ（I 型）。分棟率 60 〜 $80 \%$ 、別食 率 $50 \%$ 以上と、分棟率がやや低いものの、別食率は第 1 グループに

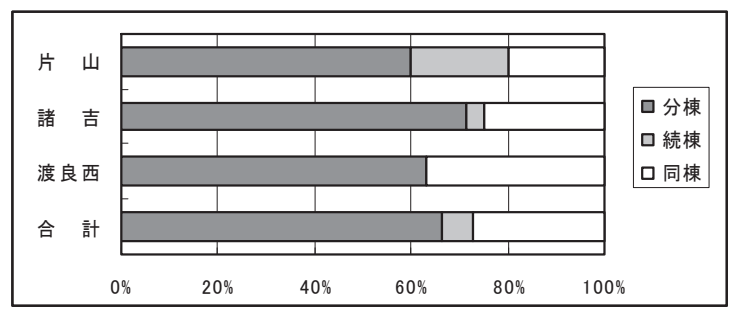

図 4 居住形態類型別構成比率
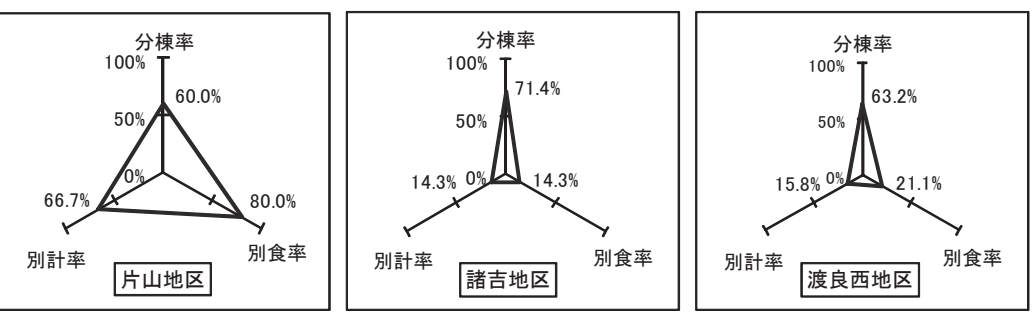

図 5 分棟率 $\cdot$ 別食率・別計率 
匹敵する第 2 グループ（II 型）。分棟率 60〜 $80 \%$ 、別食率 $50 \%$ 未満 と、共に低い第 3 グループ（III型）である。

この結果から、各地区における隠居慣行の継承と変容についての 相対的な位置関係を見て取ることができる。すなわち、I 型は、寝 室を中心とする基本的生活空間の分離度および食事形態に代表され る日常生活の相互独立性が共に高く、旧来の隠居慣行を色濃く継承 しているものと解釈でき、「安定継承型」と称することが適当と考え られる。II 型は、父子二世代不同居の原則が少々崩れつつある反面、 まだかなりの程度維持されてもいることから、「不安定継承型」と称 寸ることができよう。III型は、基本的生活空間の分離度がやや低い のに加え、食事形態を始めとする日常生活の一体化が際立っており、 「変容進行型」と称することが妥当であるう。

以上の分類の結果、壱岐島には「安定継承型」に属する地区はな く、慣行継承の安定度は決して高くはないこと、片山地区が「不安 定継承型」に属し、辛うじて旧来の慣行を継承しているものの、諸 吉地区および渡良西地区は「変容進行型」に属し、大幅な変化が認 められることが判明した。

\section{5 同棟化の要因}

以上、壱岐島では 3 地区により差異はみられるものの、分棟居住 の割合が減少し、それに代わって同棟居住が増加する傾向が推定で きる。居住者へのヒアリングによると、表 4 に示すように、親の老 齢化や配偶者の喪失による自活能力の低下などの年齢的要因、隠居 屋の維持更新費用や日常生活上の二重経済に対する負担能力の低下 などの経済的要因をその二大要因として挙げることができる。

この経済的要因に関して、固定資産税を親子のいずれが負担して いるか、その実態を示したものが表 5 である。これによると、子世 帯が負担しているものが圧倒的に多く、親世帯の経済力の脆弱さが 分棟居住から撤退させる要因の 1 つであることを示唆している。

一方、親がまだ現役で家の実権を子に移譲するに至らず、子夫婦 も共働きのため家事全般を掌握することが困難なため暫定的に同棟 を選択する場合もみられる。

さらに、同じ暫定的な同棟でも、表 6 に示寸片山地区のように、 家風見習いと称して、第一子が生まれるまでの期間を目途としてし ばらく同棟居住を経験した後に分棟居住に移行するケースもみられ る。なお、このような慣習は、過去に他の 2 地区でも行われていた が、今では片山地区のみに残る慣習となっている。分棟居住でも親 子二世帯の共食など生活の一体化が進み、分棟への移行を前提とし た家風見習いの必要性が希薄になったことによるものと推察される。

\section{6. 親子両世帯の居住領域構成}

本章では、家屋構成等との関係を含めて、親子両世帯の居住関係 の詳細に立ち入り、各地区における隠居慣行の特質を明らかにする。

\section{1 屋敷および家屋構成}

壱岐島の各集落は、各屋敷が集落の中に点在する特有の散居形態 を成す。各屋敷は、図 $7^{\text {注 }}{ }^{5)}$ に示寸ように、かつて本家、隠居屋、納 屋、牛舎、便所などで構成されており、これらの各棟が背戸山と呼 ばれる北側の防風林を背にし、ホカと呼ばれる中庭の周りに配置さ れる形態が一般的であった。図 8 (写真 1 参照) に示すように、現 在でもこの基本形に変わりはない。ただし、大正後期以後、台所・ 食事場の機能を有する釜屋と呼ばれる家屋が、中庭を介して本家の

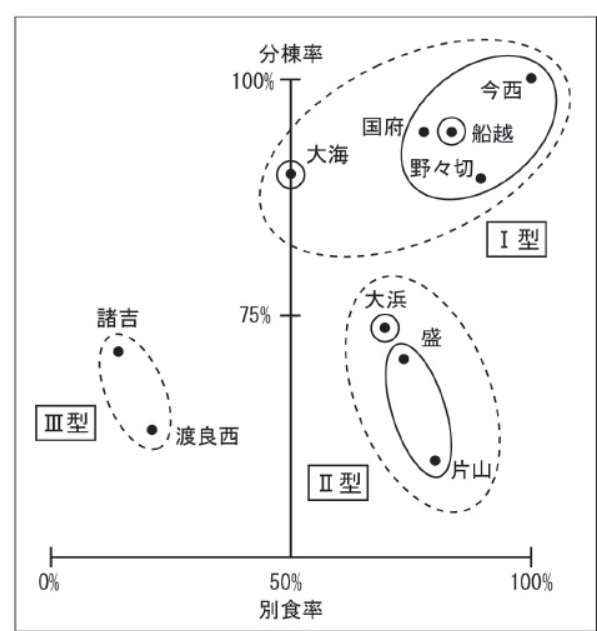

図 6 分棟率・別食率による類型化

表 4 同棟化の要因

\begin{tabular}{|c|c|c|c|c|c|c|c|}
\hline \multirow{2}{*}{$\begin{array}{l}\text { 要因 } \\
\text { 地区名 }\end{array}$} & \multicolumn{2}{|c|}{ 経済的要因 } & \multicolumn{2}{|c|}{ 年齢的要因 } & \multirow{2}{*}{$\begin{array}{l}\text { 親夫婦に } \\
\text { よる家事 } \\
\text { 肾支援 }\end{array}$} & \multirow[b]{2}{*}{ 不明 } & \multirow[b]{2}{*}{ 合計 } \\
\hline & $\begin{array}{l}\text { 隠居屋の } \\
\text { 維持更新 }\end{array}$ & 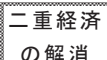 & $\begin{array}{c}\text { 家事能力 } \\
\text { の低下 }\end{array}$ & {$\left[\begin{array}{c}\text { 介護の } \\
\text { しすすさ }\end{array}\right.$} & & & \\
\hline 片 山地区 & 1 & $1^{*}$ & 1 & $1^{*}$ & 0 & 0 & 4 \\
\hline 諸 吉 地区 & 1 & $1^{*}$ & $3^{*}$ & 0 & 2 & 1 & $8 *$ \\
\hline 渡良西地区 & 2 & $2^{*}$ & $1^{*}$ & 1 & 2 & 0 & 8* \\
\hline 合 計 & & 8 & & 7 & 4 & 1 & 20 \\
\hline
\end{tabular}

表 5 固定資産税の支払者

\begin{tabular}{|c|c|c|c|c|c|c|}
\hline $\begin{array}{r}\text { 支払者 } \\
\text { 地区名 }\end{array}$ & 親 & 子 & 別々 & 共同 & 不明 & 合計 \\
\hline 片 山 地区 & 2 & 10 & 1 & 0 & 2 & 15 \\
\hline 諸 吉 地区 & 6 & 19 & 1 & 2 & 0 & 28 \\
\hline 渡良西地区 & 4 & 12 & 0 & 1 & 2 & 19 \\
\hline 合 計 & 12 & 41 & 2 & 3 & 4 & 62 \\
\hline
\end{tabular}

表 6 居住形態の変化

\begin{tabular}{|c|c|c|c|c|}
\hline \multirow{2}{*}{ 変化の有無 } & \multirow{2}{*}{ 変化のパターン } & \multicolumn{3}{|c|}{ 地区名 } \\
\cline { 3 - 5 } & & 片 山 & 諸 吉 & 渡良西 \\
\hline 不変 & 最初から分棟のまま & 2 & 19 & 11 \\
\hline \multirow{3}{*}{ 変化 } & 同棟 $\rightarrow$ 分棟 & 7 & 1 & 1 \\
\cline { 2 - 5 } & 同棟 $\rightarrow$ 続棟 & 1 & 1 & 0 \\
\cline { 2 - 5 } & 分棟 $\rightarrow$ 続棟 & 2 & 0 & 0 \\
\cline { 2 - 5 } & 分棟 $\rightarrow$ 同棟 & 0 & 2 & 1 \\
\hline 不変 & 最初から同棟のまま & 3 & 5 & 6 \\
\hline \multicolumn{2}{|c|}{ 合 計 } & 15 & 28 & 19 \\
\hline
\end{tabular}

正面付近に加わることになった (表 9 中、事例 5 および事例 6 参照)。 煙草生産による多忙さを背景とする家事の軽減および本家の防火が その目的と伝えられている。ただし、この釜屋は島内の全ての集落 において普及したわけではない。本論文の対象集落のうち、諸吉地 区および渡良西地区では一般化したものの、片山地区では全く出現 していない。後述するように、この釜屋の有無が親子の居住形態の 継承と変容にかなりの影響を与える結果となっている。

\section{2 釜屋の有無と居住形態との相関}

表 7 は、各地区毎に、釜屋の有無および使用状況と居住形態との 相関をみたものである。これによると、上述のように、片山地区で は、いずれの居住形態においても全く釜屋が存在しておらず、古く から継承されている家屋構成を保持していることが明らかである。 他方、諸吉地区では、釜屋を有し、かつ使用している世帯が地区全 
体の $71 \%$ 占める。渡良西地区でもかつては多数の釜屋が使用され ていたが、最近はあっても使用しないケースが増え、21\%にとどま っている。注目す心゙きは、両地区共に、釜屋を使用している世帯の $80 \%$ 前後が分棟居住で占められている一方、釜屋を使用していない 世帯では、分棟居住と同棟居住がほぼ同率で、分棟居住の比率が相 対的に低くなっており、釜屋の使用の有無と居住形態との間には相 関が認められる。後述するように、このことが親子両世帯の居住領 域構成に少なからぬ影響を与えている。

\section{3 分棟居住における親子両世帯の居住領域構成}

隠居慣行は、親世帯が隠居屋を拠点としてその生活を展開する居 住形態ではあるものの、家屋構成や子世帯との居住関係により親子 両世帯の生活エリアの広がりと関わりはそれぞれ異なる。ここでは、 親子両世帯の生活エリアの広がりと関わりを居住領域構成と称し、 実態に即していくつかの類型に区分することを通して、その詳細を 把握する。類型化に用いた指標は、親世帯の(1)就寝場所、(2)食事形 態および食事場所、(3)子世帯との交流の程度および主たる交流場所 である。分類の結果、表 8 に示すように、3つの基本的類型および 細分類を含めて合計 5 つの類型に区分することができた主 6 。 各類型の概要を示す。また、各類型の典型的事例を表 9 に示す。

\section{1）相互独立型}

就寝場所は「隠居屋」、食事も子世帯とは「別食」で、「隠居屋」 でとる。子世帯との交流は少ない。すなわち、互いに隣りあって住 んではいるものの、両世帯相互の接触・交流や支援は必要最小限に とどまり、基本的にはそれぞれほぼ完全に独立した生活を送ってい る。したがって、親世帯の大部分の生活が営まれる隠居屋の性格は 「全生活型」とみなすことができる。壱岐島でも、かつてはこの夕 イプが多数を占めていたと推察される注 7)が、慣行の変容が進行して いる現在では少数例にとどまる。

\section{2）生活交流型}

相互独立型と同じく、就寝場所は「隠居屋」、食事も子世帯とは 「別食」で「隠居屋」でとる。したがって隠居屋の性格も「全生活 型」と夕なせる。しかし、子世帯との交流は多い。交流は、本家、 隠居屋その他の随所で行われる。すなわち、基本的な生活の独立性 は高いものの、同時におかずのやり取りや孫の世話を始め相互交 流・支援も盛んであり、自立と支援のバランスが取れた居住関係を 結んでいる。旧来の慣習にしたがって親子両世帯の別食を旨とする 片山地区においてこのタイプが多数を占めている。

\section{3）生活共同型 \\ (1) 隠居拠点型}

就寝場所は「隠居屋」であるが、食事は子世帯と一緒にとる「共 食」である。しかし、その場所は本家ではなく、子世帯が隠居屋の 食事室を訪れ、食事を共に寸るという変則的なケースである。これ は、子世帯の夫が早世し、残された宾婦が親世帯への世話の見やす さを優先し、隠居屋で炊事し食事を共にし、したがって交流も多い。 親夫婦は隠居屋での生活が中心となり、隠居屋の性格は「全生活型」 とみなせる。事例は全て渡良西地区のものである。

\section{(2) 本家拠点型}

隠居拠点型と同じく、就寝は「隠居屋」、食事も子世帯と「共食」 であるが、場所は「本家」の食事室であり、子世帯との交流も多い。 交流場所は「本家」の食事室や居間を中心として随所で展開されて

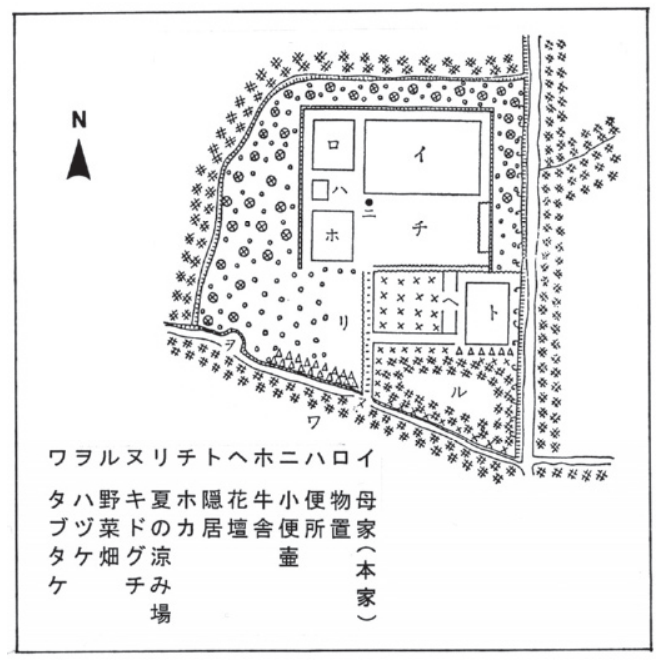

図 7 屋敷配置図（出典：参考文献 19)）

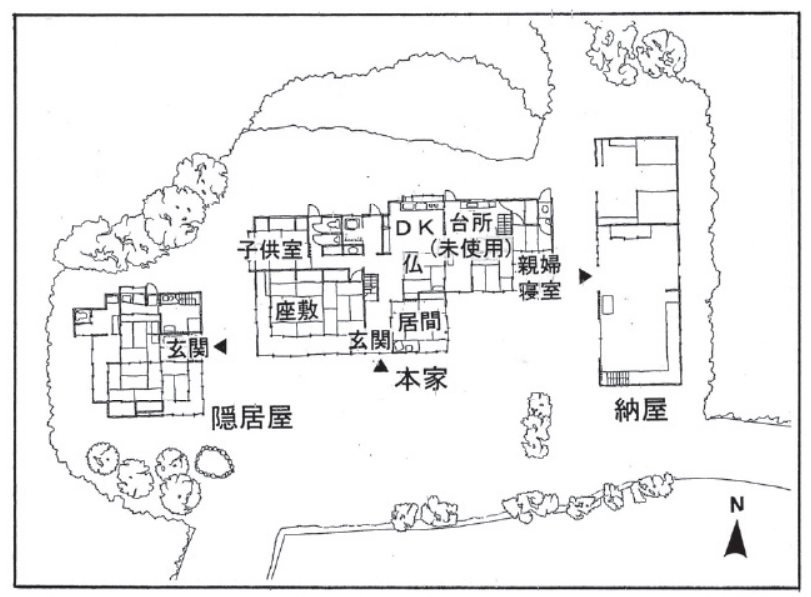

図 8 家屋配置図（壱岐市片山地区）

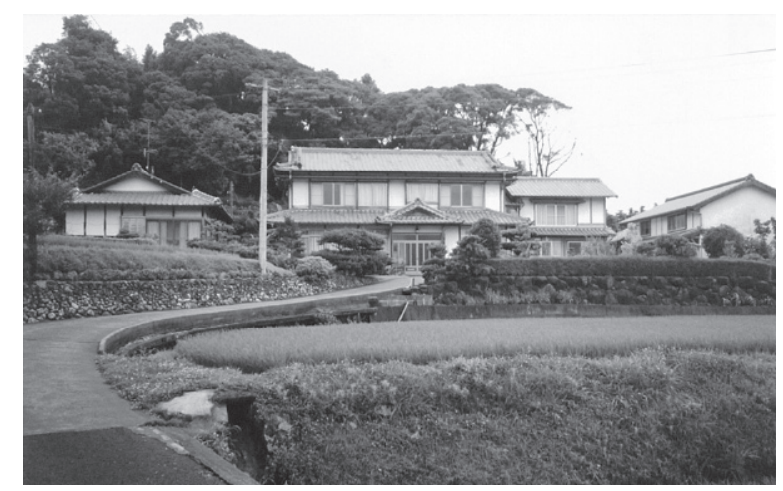

写真 1 家屋写真（壱岐市片山地区）

表 7 釜屋の使用と居住形態との相関

\begin{tabular}{|c|c|c|c|c|c|c|}
\hline \multirow{2}{*}{ 地区名 } & \multirow{2}{*}{ 釜屋使用の有無 } & \multicolumn{4}{|c|}{ 居住形態別比率 (\%) } & \multirow{2}{*}{\begin{tabular}{|l} 
使用·非使用 \\
の比率 (\%)
\end{tabular}} \\
\hline & & 分棟 & 続棟 & 同棟 & 小計 & \\
\hline \multirow{3}{*}{ 片山 } & 使用 & - & - & - & - & - \\
\hline & 無し又は非使用 & $9(60.0)$ & $3(20.0)$ & $3(20.0)$ & $15(100.0)$ & $15(100.0)$ \\
\hline & 小計 & $9(60.0)$ & $3(20.0)$ & $3(20.0)$ & $15(100.0)$ & $15(100.0)$ \\
\hline \multirow{3}{*}{ 諸 吉 } & 使用 & $16(80.0)$ & $0(0.0)$ & $4(20.0)$ & $20(100.0)$ & $20(71.4)$ \\
\hline & 無し又は非使用 & $4(50.0)$ & $1(12.5)$ & $3(37.5)$ & $8(100.0)$ & $8(28.6)$ \\
\hline & 小計 & $20(71.4)$ & $1(3.6)$ & $7(25.0)$ & $28(100.0)$ & $28(100.0)$ \\
\hline \multirow{3}{*}{ 渡良西 } & 使用 & $3(75.0)$ & $0(0.0)$ & $1(25.0)$ & $4(100.0)$ & $4(21.0)$ \\
\hline & 無し又は非使用 & $9(60.0)$ & $0(0.0)$ & $6(40.0)$ & $15(100.0)$ & $15(79.0)$ \\
\hline & 小計 & $12(63.2)$ & $0(0.0)$ & $7(36.8)$ & $19(100.0)$ & $19(100.0)$ \\
\hline
\end{tabular}


おり、特に夕食後の団らんは盛んである。親世帯が昼間の生活の一 部を本家で送るケースもみられる。この場合、隠居屋の性格は「私 室型」とみなせる。事例の多くは渡良西地区のものである。

\section{(3) 共用空間拠点型}

隠居拠点型あるいは本家拠点型と同じく、就寝は「隠居屋」、食事 も子世帯と「共食」であるが、場所は「釜屋」である。釜屋では、 食事だけにとどまらず、就寝やごく私的な行為を除き、食事や家族 団らんをはじめ親子両世帯の生活のほとんどが営まれている。すな わち親子両世帯の共用の居間として活用されている。隠居屋はほと んど就寝場所としての機能にとどまり「寝室型」とみなせる。諸吉 地区の大半の世帯がこのタイプで占められているが、渡良西地区に おいても、かつてはかなりの割合を示していた。

ところで、共用空間である釜屋についての居住者の評価は、表 9 中の事例 5 および 6 に例示するように、極めて対照的である。事例 5 では、釜屋が親子両世帯の緩衝空間として絶妙な存在をなし、ま たそこでの共同生活が成立していることが、二重経済解消を目的と 寸る同棟居住への傾斜を避け、分棟居住が曲がりにも継承される一 因となっている。この点は、今後における隣居型住宅のあり方にも 示唆を与えるものであろう。一方、事例 6 では、親子両世帯は一日 の大半の生活を釜屋で共にしており、子世帯特に嫁の立場からみる と、同居と同じく一日中気の抜けない生活を強いられており、むし ろ干渉空間的な存在として映っている。このように共用空間の評価 は多様であり、一面的な解釈は避けなければならないが、釜屋の存 在が分棟居住の維持に大きな役割を果たしていることは間違いない。

\section{7. 将来への居住志向}

\section{1 各地区の居住志向}

隠居慣行の今後の展開と将来動向を探るために、親子両夫婦が本 来望ましいと考える居住形態についてヒアリングを試み、各地区の

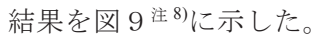

片山地区では、親子共に現在の居住形態の如何にかかわらず分棟 居住を志向するものが大勢を占めるものの、子世帯では、現状が続 棟居住あるいは同棟居住の場合は現状肯定の傾向、親世帯では分棟 居住から同棟居住への変更を希望するケースもみられる。

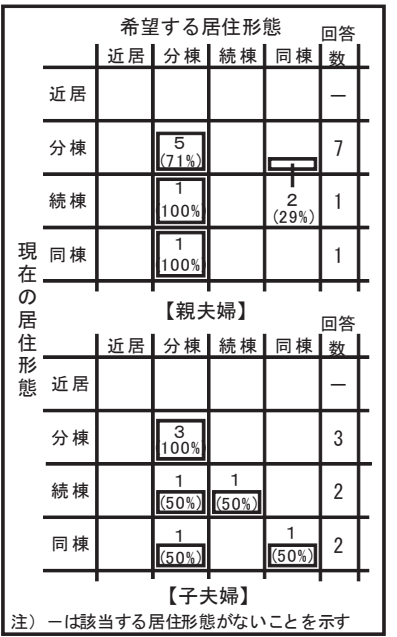

片山地区

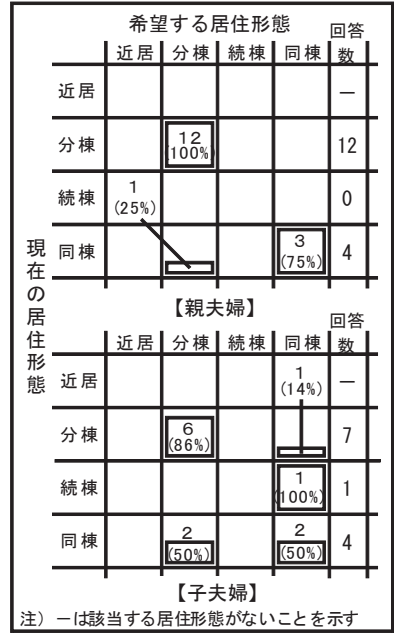

諸吉地区

図 9 親子両世帯の居住志向
表 8 親子両世帯の居住領域構成

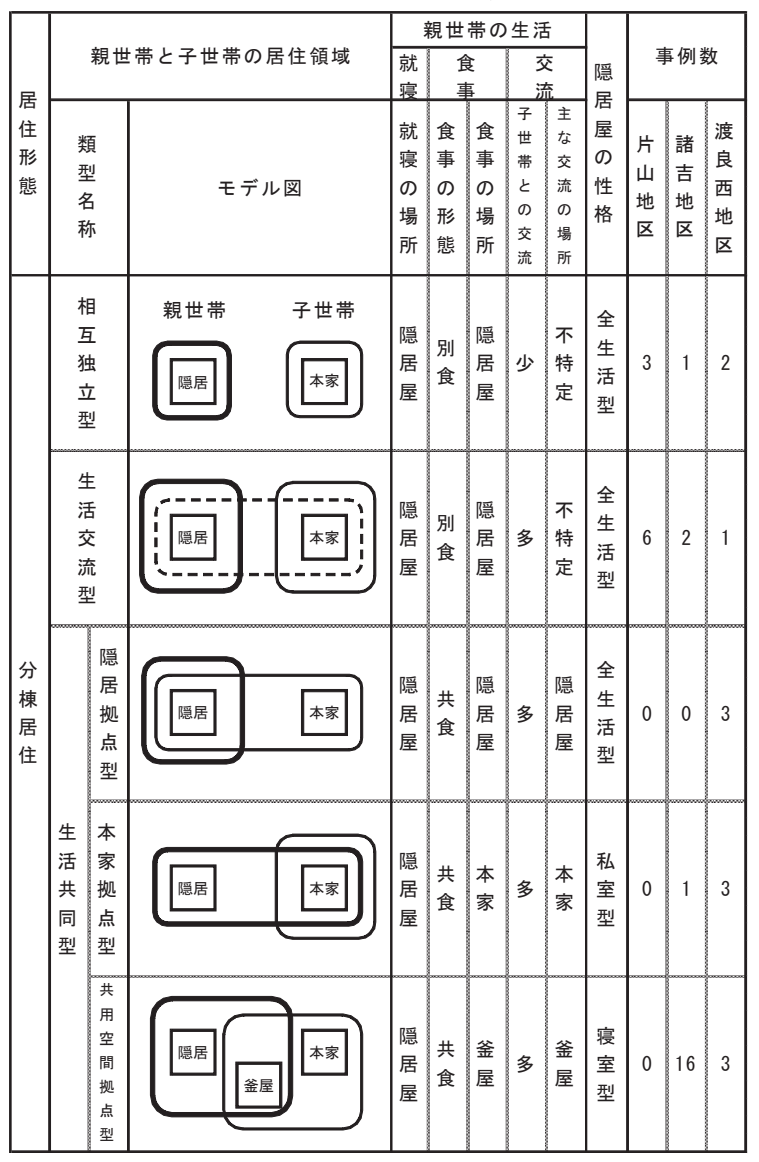

注 1) モデル図中、太線で囲った範囲が親世帯の行動領域

注2)「子世帯との交流」における多少の判定は、親夫婦の本家への出入りの頻度による。 ただし、「隠居拠点型」は子夫婦の隠居屋への出入り、「共用空間拠点型」は親子 両夫婦の共用空間 (釜屋)への出入りの頻度により判定した。

諸吉地区および渡良西地区においても総じて分棟居住を希望する 傾向が認められる。しかし反面、現在、同棟居住の場合、その現状 を肯定する傾向もみられ、特に親世帯に顕著である。

\section{2 分棟居住への評価}

上述のように、分棟居住すなわち隣居については親子間で微妙に 評価が分かれる。ここでは、同じく居住者へのヒアリングから、分 棟居住の肯定あるいは否定の理由につい

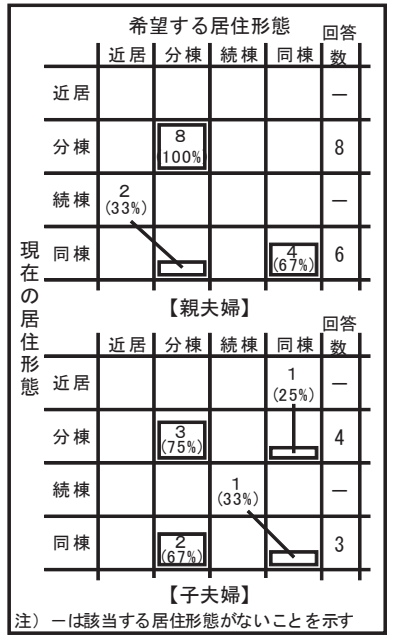

渡良西地区 て整理しておく。なお、評価は、分棟居住 が親子間の相互独立性が高い居住形態で あるとの見地に立ってなされたものと、そ れとは全く逆に、近居などに比較すると相 互独立性が低いとの見地に立つものに分 かれることから、それぞれ区別して以下に 示す。

まず、前者の相互独立性が高いとの見地 に立っての支持理由としては、親子共に、 分棟居住は「相互干渉が少ない、気兼ねし なくてもよい、プライバシー保護が可能」 「生活時間の違いへの気遣いが不要」「食 べ物の嗜好の違いへの対応が容易」など生 活の独立性を評価する理由が挙げられて いる。また、親夫婦からは「生活の張りが 
表 9 居住領域構成類型別事例

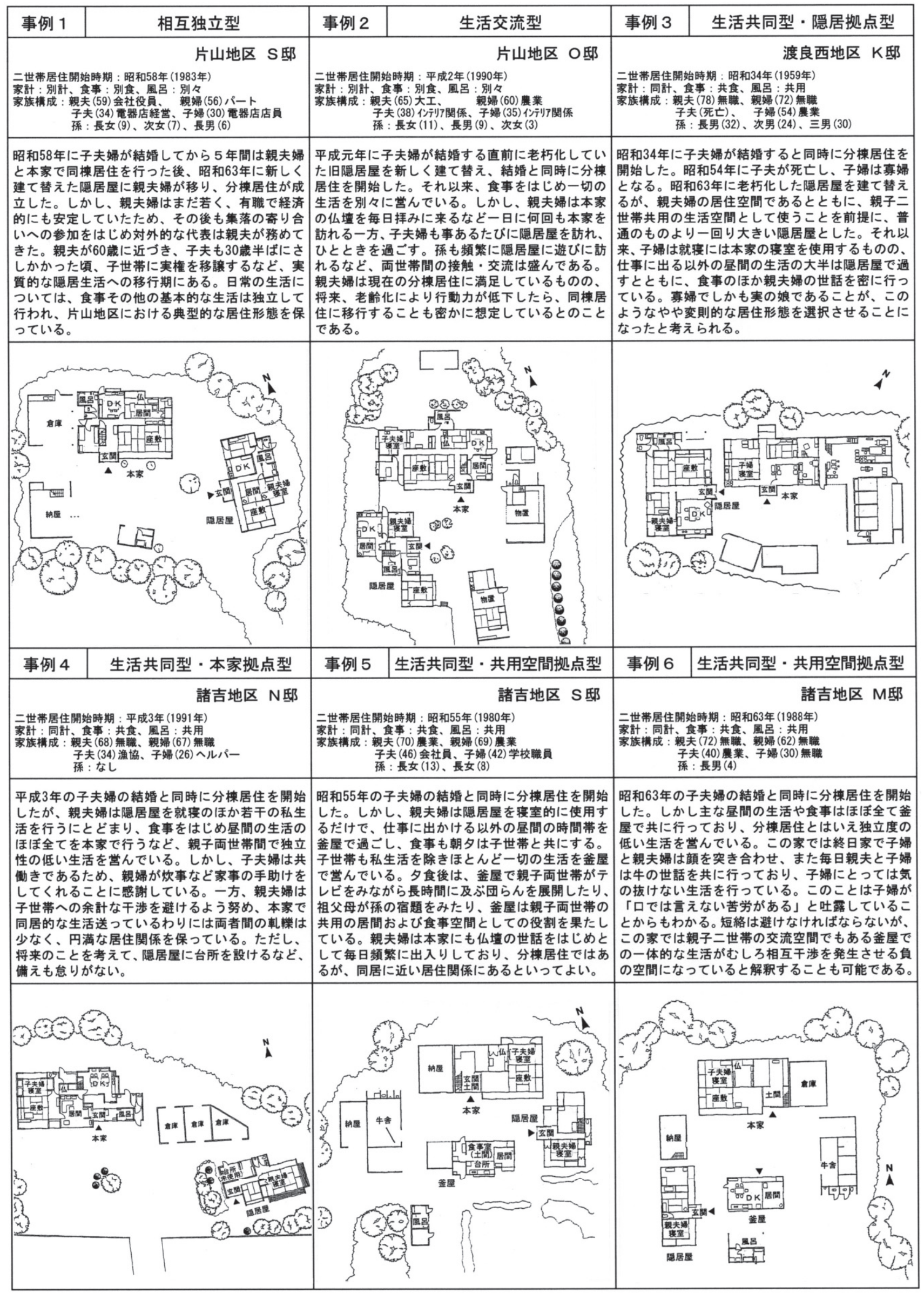


出る」といった自立性の効果を評価する声もある。一方、分棟居住 の欠点としては、「他人行儀になり、親子の絆が弱くなる」「意思疎 通に欠ける」「家風の伝承が困難」など精神面における危惧のほか、 「老齢化や発病した時に世話をしてくれるかわからない」といった 切実な不安も吐露されている。

次に、後者の相互独立性が低いとの見地に立つものでは、親夫婦 では「近くにいるので何となく安心」といった情緒的な評価が多く、 一方、子夫婦では「孫の世話など相互支援を得やすい」「火急の際に 素早い対応が可能」など実利的な利点が指摘されている。また、久 点としては、そのほとんどが子夫婦から寄せられたものであるが、 「分棟とはいえ近過ぎて親からの干渉を受けやすい」「気兼対する」 「孫を甘やか寸」など、同居への批判と誤解しそうな指摘がなされ ている。隣居といっても、親世帯と隣合わせの居住形態は同居と大 差ないとの評価意識もうかがえる。

\section{8.まとめ}

本研究は、親子両世帯の居住関係における多様化現象の解明およ び隣居型居住への示唆を得ることを目的とし、西日本各地の隠居慣 行継承地域との比較を視野に置き、長崎県壱岐島における隠居慣行 を対象として行った事例研究であり、以下の結果を得た。

壱岐島内の各地では、今なお必要に応じて隠居屋が更新されてお り、隠居慣行は継承されているといってよい。しかし一方、本家 (壱 岐では母屋のことを指す）の建て替えの際に、老朽化した隠居屋を 撤去して同棟居住すなわち同居型居住に移行するなど、隠居慣行か らの離脱の一面もみられる。

居住形態、食事形態および家計における親子間での分離度から慣 行の継承と変容の実相を概覽すると、壱岐では、この 3 要素におけ る分離度が高い「安定継承型」の事例は皆無であるものの、ある程 度高い数值を示す「不安定継承型」、食事形態および家計における分 離度の低下が著しい「変容進行型」が存在することが判明した。ま た、このように分棟居住すなわち隣居型居住が減少する要因として、 親の老齢化や配偶者の喪失による自活能力の低下などの年齢的要因、 隠居屋の維持更新費用や日常生活上の二重経済に対する負担能力の 低下などの経済的要因が挙げられる。

次に、就寝と食事における分離度に加えて交流の状況を加味して 親子両世帯の居住領域構成を類型化したところ、全ての生活行為に おいて分離度が極めて高い「相互独立型」、基本的な生活の分離度は 高いものの、他方で交流も盛んな「生活交流型」、就寝場所の分離を 除く生活行為の一体化が著しい「生活共同型」の 3 タイプに区分さ れた。また、「生活共同型」は、共同生活の拠点の置かれ方により、 「隠居拠点型」、「本家拠点型」、「共用空間拠点型」に区分される。

このうち、「共用空間拠点型」では、共用空間である釜屋が分棟居 住を維持する役割を果たしていること、また親子両世帯の緩衝空間 としての存在意義を有する反面、逆に干渉空間として働く場合もあ り、両義性を有するという、今後の隣居型住宅を考える上での興味 深い結果を得た。

以上のように、隠居慣行の継承度と生活の実相は多様ではあるも のの、親子両世帯共に分棟居住すなわち隣居型居住を肯定的に評価 する傾向が顕著である。相互干渉を回避できるなどの心理的な効果 に加え、生活時間や食物嗜好の違いへの対応など生活上の軋軪を避
けることを可能とすることがその理由として挙げられる。

なお、研究の目的と方法の章でふれた「現代における隣居の有効 性と可能性および問題点」については、一連の続報の後にまとめて 論及したいと考えている。

注

注1) 概衩車で 1 時間以内で往来できる範囲の居住関係。参考文献3)を参照のこと。 注 2) 参考文献 17)中で使用されている「同棟型」「続棟型」の表記を参考にした。

注 3) この場合の食事とは夕食である。ただし、一部の例外を除き朝食と夕食の形 態が異なる事例はみられなかった。

注 4) 家計における基本的な支出項目は「食費」および「水道光熱費」である。

注 5) 参考文献 19)から転載した。

注 6) 参考文献 20)中で使用されている分類方法を参考にした。

注 7) 参考文献 19）中に「䊍領息子にヨメゴをとってくれ、孫でも出来れば、普 通両親は隠居寸る。(中略) この場合には残った子供は隠居につれてはいり、 他の子供たちとの交際もここで別にする。とあり、「相互独立型」が一般的 であったことが推察される。

注 8) 親子両世帯ともに、回答が寄せられたものによる。

\section{参考文献}

1) 船越正啓・上和田茂・青木正夫 : 西日本地域の農漁村における隠居慣行の様 相、隠居慣行の継承と変容に関寸る研究、日本建築学会計画系論文集、

第 614 号、pp1-8、2007.4

2) 上和田茂・船越正啓・青木正夫 : 隠居慣行からみた隣居型親子二世帯居住の 動向、老親は誰と暮らしたいか、長崎県壱岐島のケース、住宅系研究論文報告 会論文集 1、pp177-184、2006.12,

3) 上和田茂・鳥飼香代子ほか：準近居からみた老親世帯の自立と支援を止揚す るサポート居住の動向、日本建築学会計画系論文集、第 566 号、pp9-16、2003.4 4) 文化庁文化財保護部監修:日本民俗資料事典、第一法規、pp216-221、1969

5) 大塚民俗学会編：日本民俗辞典、弘文堂、1972

6) 大間知篤三: 親族集団・家族、「日本民族大系 3 、社会と民俗 $($ 一) 」、平凡社、 pp220-232、1958 (1985 復刊)

7) 竹田旦 : 民俗慣行としての隠居の研究、未来社、1964（復刊 1992）

8) 竹田旦: 家をめぐる民俗研究、「第八章 隠居慣行の変移とその系統」、弘文堂、 pp206-239、1970,

9）郷田洋文：社会規制・互助協会、「日本民族大系 4 社会と民俗（二）」所収、 平凡社、pp146-153、1959（復刊 1985）

10) 南山大学文化人類学研究会: 三重県志摩郡大王町船越地区調查報告、文化人 類学研究会会報、Vol.9、1976.7

11）増田武夫:現代の家と別居構造に関する一試論、東京都利島村における隠居慣 行の変容と家継承の問題をめぐって、日本民族学、No.221、pp33-64、2000.2

12）野村孝文ほか: 壱岐の集落および民家その 1 ・その 2、日本建築学会九州支部 研究報告、pp21-28、1971.2

13) 系長浩司ほか: 農家住宅における同居形態に関する事例研究、日本建築学会 大会学術講演梗概集、pp1817-1818、1983.9

14) 加藤仁美・加藤武弘 : 壱岐における散居集落の研究、その 2 集落の社会・空 間構造について、日本建築学会大会学術講演梗概集E、pp925 -926、1987.10、 その 6 屋敷廻りの空間構造について、日本建築学会大会学術講演梗概集 E、 pp893 -894、1989.10

15) 加藤仁美ほか : 壱岐島における散居集落の研究その 1 その9、日本建築学会 大会九州支部研究報告、1987 1991

16) 伊藤庸一・岡部雅美：通世代同居家族の住み方にみる家共同体、その 1 同棟 同居事例、その 2 別棟・隠居事例、日本建築学会大会学術講演梗概集 $\mathrm{E} 、 \mathrm{pp} 987$ $-990 、 1990.10$

17) 重村力・河崎晶子 : 農村家族の世代同居にみる居住様式と住空間に関寸る研 究その $1 \cdot 2$ 、日本建築学会大会学術講演梗概集 E、pp951 -954、1991.9

18）岡部雅美・伊藤庸一:農村住居における生活単位と住まい方を通してみた通世 代家族の住空間、日本建築学会計画系論文集、第 477 号、pp125-132、1995.11 19) 山口麻太郎 : 壱岐島民俗誌、一誠社、pp214、1934

20) 在塚礼子 : 老年期の住み方変化に関する研究、住宅建築研究所報、新住宅普 及会、pp169-180、1982

21) 杉本尚次 : 九州地方の民家、明玄書房、1977

22) 西山外三 : 日本の寸まいIII、勁草書房、1980

23）久保清・橋浦泰雄 : 五島民俗圖誌、一誠社、1934（復刊 1974、国書刊行会） 